\title{
YAŞLI BAKIM İSTIHDAMINDA YAŞLANMA VE YAŞLILIK ALGISI
} AGING AND OLD AGE PERCEPTION IN ELDERLY CARE EMPLOYMENT

\author{
Işıl KALAYCI ${ }^{1}$, Metin ÖZKUL ${ }^{2}$, Meyrem TUNA UYSAL ${ }^{3}$
}

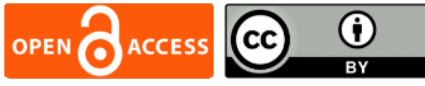

1. Doç. Dr., Süleyman Demirel Üniversitesi, Sağlık Bilimleri Fakültesi, Hemşirelik Bölümü, isilkalayci@sdu.edu.tr,

https://orcid.org/0000-0003-1562-2120

2. Prof. Dr., Süleyman Demirel Üniversitesi, Fen Edebiyat Fakültesi, Sosyoloji Bölümü, metinozkul@sdu.edu.tr,

https://orcid.org/0000-0003-2511-9780

3. Doç. Dr., Süleyman Demirel Üniversitesi, Süleyman Demirel Üniversitesi, Fen Edebiyat Fakültesi, Sosyoloji Bölümü, meyremtuna@sdu.edu.tr, https://orcid.org/0000-0001-8910-8058

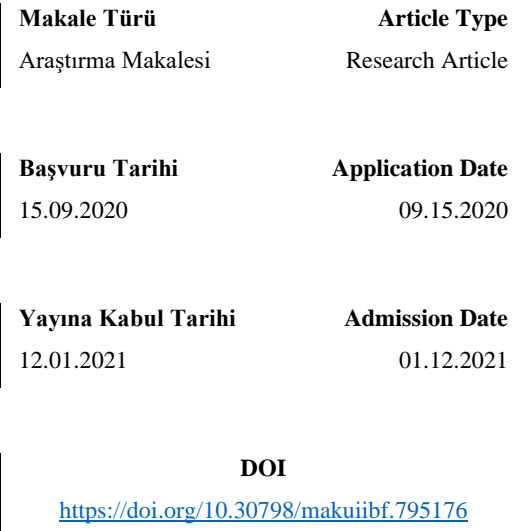

https://doi.org/10.30798/makuiibf.795176
$\ddot{O} z$

Araştırmanın amacı yaşlı bakım istihdamında yer almak maksadıyla eğitim alan bireylerin yașlanmaya ve yaşlılara yönelik algılarını betimlemek ve araștırmanın bulguları ile literatürdeki benzer çalışmaları dikkate alarak yaşlı bakımıyla ilgili davranışların toplumsal nedenlerini belirlemek ve anlamsal içeriklerini tanımlamaktır. Araştırmada nitel araştırma yöntemi kullanılmıştır. Araştırma "Öz bakıma destek elemanı kursu"nu tamamlayıp sertifika alan 26 bireyden oluşmaktadır. Araştırmada, katılımcıların "yaşlı hissetme, yașlanmaktan korkma, dıș görünüșlerinde ortaya çıkan değişikliklerden rahatsız olma" temaları çerçevesinde kendi yaşlanmalarına yönelik algıları değerlendirilmiştir. Aynı zamanda katılımcıların genel yaşlılık algıları tartıșılmıștır. Katılımcıların büyük bir kısmının yaşlılıktan korkmadıkları, görece ileri yaşta olanların yaşın ilerlemesiyle birlikte dış görünüşlerinde ortaya çıkan değişikliklerden rahatsızlık duydukları, "emeklilik, muhtaçlık, yalnızlık" gibi kavramlara yer vererek yaşlı kelimesine ve yaşlılık dönemine olumsuz anlamlar yükledikleri tespit edilmiştir.

Anahtar Kelimeler: Yaşlanma, Yaşlılık, Yaşlı Bakımı, Algı, İstihdam.

\section{Abstract}

The aim of the research was to describe the perceptions of individuals who are trained to take part in elderly care employment towards aging and older individuals, to identify the social reasons of elderly care-related behaviors by considering the findings of the research and similar studies in the literature, and to define their semantic content. Qualitative research method was used in the research. .The research consists of 26 individuals who have completed the "Self-care support staff course". In the research, participants' perceptions of their own aging were evaluated within the framework of the themes of "feeling old, afraid of aging, being uncomfortable with changes in their appearance At the same time, the participants' general perceptions of old age were discussed. It was determined that the majority of the participants were not afraid of old age, those who were of relatively advanced age were disturbed by the changes in their external appearance with the advancement of age, and they gave negative meanings to the word "old age" and "old age" by including concepts such as retirement, neediness, loneliness.

Keywords: Aging, Old Age, Elderly Care, Perception, Employment. 


\section{Research Problem}

\section{EXTENDED SUMMARY}

Research focuses on how individuals who are trained to take part in the employment of aged care create a perception of their own aging and what perceptions they have for older individuals.

\section{Research Questions}

The following questions were imposed to participants within the scope of the research: 1 . What perception does participants create on their own aging who are trained to take part in elderly care employment? 2. What are the perceptions of participants who are trained to take part in aged care employment towards elderly people? With the reduction of fertility rates in the world and the prolongation of human life, the increase of the older population brings new dimensions to the perception of old age with many changing social, economic and technological conditions. In this process, older individuals are affected by socio-cultural and economic changes, changing their positions in their preold social lives, losing respect and therefore effectiveness for their social environment. Older individuals who have certain status in society, whose words are listened to, respected, have an important role in intergenerational transfer, are perceived as a source of problems due to the prolongation of life expectancy and other conditions associated with the increase of their diseases as a result (Senol and Erdem, 2017). As a harness of these changes in terms of the older person, assessments, perceptions and understandings about old age also change. Especially due to the increase in health problems in old age, old age is perceived as one of the most important problems that adversely affect everyday life for older individuals themselves and their relatives (Etiquette Baran and others, 2005). This leads to lower living standards for the older persons and their relatives, increasing their demands for health and social services (Ceylan, 2015). Therefore, with the increase of the older population, elderly care services and people who provide this service are needed to meet their health needs. However, the negative perception of elderly care providers against aging and the aged prevents this need from being carried out in the expected qualifications.

\section{Literature Review}

With the reduction of fertility rates in the world and the prolongation of human life, the increase of the elderly population brings new dimensions to the perception of old age with many changing social, economic and technological conditions. In this process, elderly individuals are affected by socio-cultural and economic changes, changing their positions in their pre-old social lives, losing respect and therefore effectiveness for their social environment. Elderly individuals who have certain status in society, whose words are listened to, respected, have an important role in intergenerational transfer, are perceived as a source of problems due to the prolongation of life expectancy and other conditions associated with the increase of their diseases as a result (Senol and Erdem, 2017). As a harness of these changes in terms of the elderly, assessments, perceptions and understandings about old age also change. Especially due to the increase in health problems in old age, old age is perceived as one of the most important problems 
that adversely affect everyday life for elderly individuals themselves and their relatives (Etiquette Baran and others, 2005). This leads to lower living standards for the elderly and elderly relatives, increasing their demands for health and social services (Ceylan, 2015). Therefore, with the increase of the elderly population, elderly care services and people who provide this service are needed to meet their health needs. However, the negative perception of elderly care providers against aging and the elderly prevents this need from being carried out in the qualifications that are expected or should be.

\section{Methodology}

Qualitative research method was used in the research. Accordingly, the research consists of 26 individuals who have completed the "Self-care support staff course" opened by Isparta Public Education Center (IHEM) and received certificates and applied for a job to work in a nursing home or expressed their desire to look after the older person at home. A semi-structured interview form was prepared in the collection of research data and the interviews were conducted by choosing an in-depth interview technique. Participants included in the sampling; Due to the outbreak of COVID 19, the home environment was accessed through programs that would allow remote conversation via the Internet, and oral approvals of the participants who agreed to participate by explaining the purpose of the research were obtained. All participants have been asked for permissions to record interviews. The interviews lasted between 60 and 90 minutes. The raw data obtained by the interviews was converted into text and combined under two conceptual themes: participants' perceptions of their own aging and general perceptions of old age. Direct citations are included to reflect the views of the participants. The results obtained from the data in the last stage were classified according to their subjects and the integrity of the meaning was ensured and interpreted.

\section{Results and Conclusions}

The meaning and value imposed on age and old age vary from society to society. Especially given the social and cultural characteristics of a society, social norms and patterns developed in relation to age change the meaning of old age and the perception of old age. From here, the research focused on two conceptual themes: the perceptions of the participants for their own aging and general perceptions of old age. In the perceptions of the participants for their own aging; the mere themes are "feeling old, not afraid of getting old, uncomfortable with changes in appearances" are included. According to the data sorted within the framework of these themes, most participants express that they are not afraid of old age. However, it was found that those of relatively advanced age were disturbed by the changes in their appearance physically and physically. This suggests that first, the 'elderly' character is based on a change in physical and physical appearance. The research also evaluated the general perceptions of the participants who want to take part in the employment of aged care within the framework of the themes of "age of old age, clothing style of the elderly, social life of the elderly, productivity of the elderly, need for care and respect for the elderly". Accordingly, participants include concepts such as "retirement, indulging, neediness, loneliness, end of life", and imposes negative meanings on the old 
word and old age. As a result, the individual differences in the perceptions of aging of the participants who want to take part in the employment of aged care also take into account the elderly individuals, the old age period, negative meanings and the old age process "neediness, being fond" at the point of conceptualizations. 


\section{GİRIŞ}

Yaşl1lık her toplumda farklı şekillerde değerlendirilmekte ve homojen bir yaşlı grubundan söz etmek mümkün görünmemektedir. Bu durum yaşl11ık sürecinin ve yaşl1lığın her topluma ya da kültüre göre farklılaştığını ve göreceli bir kavram olduğunu göstermektedir (Tufan, 2003). Özellikle yaşlı bireylerin eğitim durumu, mesleği, toplumsal konumu gibi konularda herkesin eşit olanaklara sahip olmadığı göz önüne alınırsa her birey için yaşlılık ve yaşlanma algısı farklılaşabilmektedir (Görgün Baran, 2018). Başka bir ifadeyle toplumda bireyler çeşitli farklılıklar ve eşitsizlikler içinde toplumsallaştıklarından dolayı her birey biyolojik özellikler açısından olduğu gibi sosyal ve psikolojik özellikleri bakımından da diğerlerine göre farklılaşan özgünlüklere sahip olabilmektedir. Ayrıca bireyler ekonomik koşullar bakımından da yeterliliklere ya da yetersizliklere, çeşitli imkânlara ya da imkânsızlıklara sahiptirler. Bireyler bu ve benzeri nedenler açısından ve temsil ettikleri değerler doğrultusunda, çevrelerinde olup bitenlere yönelik algıladıkları tutumlarını belirlerler. Günümüzde yaşlı bakımıyla ilgili etkinlikler ve davranışlar, toplumların nüfuslarının gittikçe yaşlanmasına paralel olarak mesleki bir uzmanlık alanı haline gelmektedir. Ancak yaşı bakımıyla ilgili geleneksel tavrın (yaşlının bakımının aile üyeleri tarafından yapılması gerektiği yargısı, kaderci ve değer yönelimli davranışlar gibi) toplumsal yaşamdaki önemini koruması nedeniyle, konuyla ilgili mesleki ve dolayısıyla standardize edilmiş uzmanlık davranışlarının ve normlarının formel ya da enformel yollarla kazanılması güçleşmektedir. Geleneksel yaşamın bireyler açısından oluşturduğu homojen bir toplumsal yaşam ve anlayış birliğinin modernleşen ve gittikçe heterojen hale gelen bir yaşam içinde sürdürülmesi her geçen gün daha da zorlaşmakta ya da imkânsız hale gelmektedir. Bu nedenle yaşlılık gibi günümüzde önemli belirtilerini gördüğümüz ve yakın gelecekte daha da önemli hale gelecek olan yaşlı nüfusun bakımına yönelik çözümlerin mesleki bir çerçevede ele alınması ve bu mesleğin temsilcilerinin yaşlılık algı ve anlamlandırmalarının, mesleğin gerektirdiği etik değerler ve kurallar açısından benzeşmeleri gerekmektedir.

Son yıllarda gerek ülkemizde gerekse dünyada nüfusun yaşlanması, sosyal, ekonomik, politik, kültürel ve sağlık da dâhil olmak üzere toplumların tüm yaşam alanlarındaki yansımaları yaşlılık olgusunu sadece bireyleri ilgilendiren bir sorun olmaktan çıkarmakta ve toplumsal bir sorun haline geldiğini göstermektedir (Mendoza-Núñez vd., 2018). Zira nüfus içerisinde yaşlı bireylerin oranının artması ve yaşlılık sürecinin uzamasıyla birlikte toplumsal yapıda yaşanan değişimler yaşlılığa yüklenilen anlam ve yaşlılık algısının değişime uğramasına neden olmaktadır (United Nations, 2020). Toplumsal değişme sürecinde göç, kentleşme, aile yapısının değişmesi, kadının çalışma yaşamında aktif rol alması, geleneklerin ve değerlerin değişime uğraması, sağlık alanındaki gelişmelerle birlikte insan ömrünün uzaması gibi nedenler (Özcan, 2013) ‘birey’ merkezli ve ‘bireyci’ bir yaşamın yaygınlaşmasını kolaylaştırmakta, modernleşmeyle birlikte görece değişen tüm bu koşullar yaşlı bireylerin aile içerisindeki bakımını, ailenin diğer üyeleri açısından hem bir angarya haline getirmekte hem de modern 
yaşamın bireye yüklediği sorumluluklar (eğitim süreçlerine ve çalışma hayatına katılma gibi) nedeniyle her geçen gün daha da zorlaşmaktadır. Bu süreçte yaşlı bireylerin, sosyo-kültürel ve ekonomik değişimlerden etkilenerek yaşl11ık öncesi toplumsal yaşamlarında sahip oldukları konumları değişmekte, toplumsal çevresi nezdinde saygınlık ve dolayısıyla etkinlik kaybına uğramaktadırlar. Toplumda belli statüye sahip olan, sözü dinlenilen, hürmet edilen, kuşaklararası aktarımda önemli rolü olan yaşlı bireyler, yaşam süresinin uzaması ve buna bağlı olarak hastalıklarının artmasıyla birlikte anılan diğer koşulların da etkisiyle bir sorun kaynağı olarak algılanır hale gelmektedirler (Şenol ve Erdem, 2017).

Yaşl1lar açısından oluşan bu değişimlere koşut olarak yaşl1lıkla ilgili değerlendirmeler, algılar ve anlayışlar da değişmektedir. Özellikle yaşlılık döneminde sağlık sorunlarının artması nedeniyle yaşlılık, yaşlı bireylerin kendileri ve kendilerinin bakımını üstlenen yakınları için gündelik yaşamı olumsuz yönde etkileyen en önemli sorunlardan biri olarak algılanmaktadır (Görgün Baran vd., 2005). $\mathrm{Bu}$ ise yaşlıların ve yaşlı yakınlarının yaşam standardının düşmesine, sağlık ve sosyal hizmetlere olan taleplerinin artmasına neden olmaktadır. Bu yüzden, yaşlı bakım hizmetlerinin sunulması hem yaşlı bireylerin hem de yaşlı yakınlarının yaşam kalitesini arttıran önemli bir unsur olarak ortaya çıkmaktadır (Ceylan, 2015).

Yaşlı nüfusunun artmasıyla birlikte, sağlı ihtiyaçlarını karşılamak için yaşlı bakım hizmetine ve bu hizmeti veren kişilere ihtiyaç duyulmaktadır. Ancak yaşlı bakım hizmeti sunanların yaşlanmaya ve yaşlılara karşı olumsuz algıları bu ihtiyacın beklenilen ya da olması gereken niteliklerde gerçekleşmesini engellemektedir. Özellikle yaşlı bakım hizmetinde yer alacak kişilerle yapılan araştırmalarda yaşlılara yönelik olumsuz tutumların olduğu ve yaşlı bireylerle çalışma isteğinin olmadığı görülmektedir (Faronbi vd., 2017; Yazıcı Özbek vd., 2015; Yazıcı Özbek vd., 2016). Yaşlı nüfusla çalışma isteğinin olmaması yaşlıya yönelik ön yargılardan ve bu önyargılar doğrultusunda tutum geliştiren genç bireylerin gerek gündelik yaşamın rutinlerinde gerekse bakım sürecinde, yaşlılıkla ilgili algılarını olumsuz bir şekilde anlamlandırmalarından kaynaklanmaktadır. Yaşlılık sürecinde ortaya çıkan, yaşlının ve bakımını üstlenen aile üyelerinin yaşadığı sorunlar "yaşl1lığın olumsuz bir şekilde anlamlandırılmasına" yönelik önyargıların da yayılmasına neden olmaktadır. Geleneksel bakış açısı ve yaşlanmayla ilgili bilgi birikiminin bu önyargılar doğrultusunda görenek yoluyla elde edilmesi, bazı araştırmacılar tarafindan, yaşlı çevresini oluşturan kişilerde "gerentofobi" oluşturduğu ifade edilmekte, bu durumun yaşlıyla ilgili somut bakım uygulamalarında, bilinçli ya da bilinçsiz şekilde ihmal ve istismar davranışlarına sebep olabildiği düşünülmektedir (Ertin ve Özkaya, 2016). Yaşlılık korkusu olarak oluşan bu anlamlandırma biçimi modern yaşamın idealize ettiği "beden imajına" yönelik kabullerle birlikte daha da pekiştirilmiş hale gelebilmektedir.

Yaşlanma algısı, yaşlıların yanı sıra yaşlıların refahı ve yaşlanma süreciyle başa çıkma konusundaki toplumsal davranış ve beklentileri de etkilemektedir. Bu alandaki çalışmaların çoğu Batı kültüründeki yaşlanma algılarındaki bireysel farklılıklara odaklanmaktadır. Ancak yaşlanma 
görüşlerinin kültürler arasında da farklılık gösterebileceğine dair kanıtlar artmaktadır (Löckenhoff vd., 2009).

Araştırma yaşlı bakım istihdamında yer almak amacıyla eğitim alan bireylerin hem kendi yaşlanmalarına yönelik nasıl bir algı oluşturdukları hem de yaşlı bireylere yönelik ne tür algılarının olduğu üzerine odaklanmaktadır. Yaşlılara yönelik özel eğitimli bireylerin yaşlılıkla ilgili algılar ve yargılar açısından benzerlik içinde olmaları araştırma öncesi beklentilerimizden biri olmuştur. $\mathrm{Bu}$ çerçevede araştırmanın amacı yaşlı bakım istihdamında yer almak için eğitim alan bireylerin yaşlanma ve yaşlı bireylere yönelik algılarının betimlemek, araştırmanın bulguları ve literatürdeki benzer çalışmaları dikkate alarak yaşlı bakımıyla ilgili davranışların toplumsal nedenlerini tespit ederek anlamsal içeriklerini tanımlamaktır.

\section{YÖNTEM}

Yaşlı bakım istihdamında yer almak için eğitim alan bireylerin yaşlanma ve yaşlı bireylere yönelik algılarının betimlemeyi amaçlayan bu araştırmada nitel araştırma yöntemi kullanılmıştır. Buna göre araştırma Isparta Halk Eğitim Merkezi (IHEM) tarafından açılan "Öz bakıma destek elemanı kursunu" tamamlayıp sertifika alan ve huzurevinde çalışmak için iş başvurusunda bulunan veya evde yaşlı bakmak istediğini ifade eden 26 bireyden oluşmaktadır. Araştırma 20-30 Nisan 2020 tarihleri arasında yapılmış olup, katılımcılara kartopu örnekleme yöntemiyle ulaşıllmıştır. Katılımcıların kimliklerini gizli tutmak için YB-1, YB-2, YB-3..... YB-26 şeklinde kod isimler kullanılmıştır.

Katılımcıların 18-60 yaş aralığında olmasına, araştırmaya katılmaya gönüllü olmasına, “Öz bakıma destek elemanı kursunu" başarıyla tamamlayarak sertifika almaya hak kazanmasına, evinde interneti olmasına ve internet aracılığıyla uzaktan görüşme olanağı sağlayacak programları kullanabilmesine, sözel, işitsel ve bilişsel engeli olmamasına önem verilmiştir.

Süleyman Demirel Üniversitesi’nin ilgili birimi tarafından 16.04.2020/108 karar no.lu yazı ile etik kurul izni alınmıştır. Veri toplanmasında, araştırmacılar tarafından ilgili literatür incelenmiş ve yarı yapılandırılmış görüşme formu hazırlanmıştır. Soru formunun ilk bölümü, katılımcıların sosyal ve demografik özelliklerini içermektedir. İkinci bölümü katılımcıların, kendilerinin yaşlanmasına yönelik algılarını, üçüncü bölümü ise genel yaşlılık algısını belirlemeye yönelik sorulardan oluşmaktadır. Bu yöntem dâhilinde veri toplanırken derinlemesine görüşme tekniği tercih edilmiştir. Örnekleme dâhil edilen katılımcılara; COVID 19 salgını nedeniyle ev ortamında, internet aracıllı̆̆yla uzaktan görüşme olanağı sağlayacak programlar aracılığıyla araştırmanın amacı açıklanmış ve katılmayı kabul eden katılımcıların sözlü onayları alınmıştır. Görüşmelerin ses kaydına alınması için tüm katılımcıların izinleri istenmiştir. Görüşmeler 60-90 dakika arasında sürmüştür Katılımcılarla yapılacak olan bireysel görüşmelerin, yaşlanmaya ve yaşlılığa yönelik görüşler hakkında fikir sahibi olunmasını ve daha dinamik tartışmalar yapılmasını sağlayacağı öngörülmüştür. 
Görüşmeler sonucu elde edilen ham veriler metne dönüştürülmüş ve katılımcıların kendi yaşlanmalarına yönelik algıları ve genel yaşlılık algıları olmak üzere iki kavramsal tema altında birleştirilmiştir. Ardından kavramsal temalar üzerinden ikinci dereceden bir kodlama çerçevesi geliştirilmişsir. Katılımcıların kendi yaşlanmalarına yönelik algılarının alt temaları "yaşlı hissetme, yaşlanmaktan korkma, dış görünüşlerinde ortaya çıkan değişikliklerden rahatsız olmak" tan oluşmaktadır. Genel yaşlılık algısının alt temaları ise "yaşlı kelimesinin anlamı, yaşlılık yaşı, yaşlıların giyim tarzı, yaşlıların sosyal yaşamı, yaşlıların üretkenlikleri, bakıma muhtaçlık, yaşlılara saygı göstermek" tir. Temaların belirlenmesinde tutarlılığın sağlanması için üç yazar tarafindan yapılan kodlamalar, bağımsız olarak karşılaştırılarak değerlendirilmiştir. Kodlamaların eşleşmediği durumlarda, yaşlılık konusu üzerinde çalışan iki bağımsız akademisyenin önerileri dikkate alınmıştır. Katılımcıların görüşlerini yansıtmak için doğrudan alıntılara yer verilmiştir. Verilerden elde edilen sonuçlar, konularına göre sınıflandırılarak anlam bütünlüğü sağlanmış ve yorumlanmıştır. Bu makalede, sayfa sayısının sınırlılığı dikkate alınmış ve konuyla ilişkili olarak katılımcıların sınırlı sayıdaki görüşlerine yer verilmiştir.

\section{BULGULAR}

\subsection{Demografik Özellikler}

Katılımcıların 22'si kadın ve 4'ü erkektir. 7 katılımcı ilköğretim kurumundan, 14 katılımcı ortaöğretim kurumundan ve 5 katılımc1 ise yükseköğretim kurumundan mezundur. 16 katılımc1 il merkezinde, 10 katılımcı ise köyde ikamet etmektedir. Katılımcıların 18'i gelirini orta düzey ve 8's1 alt düzey olarak tanımlamaktadır. Katılımcılardan 20's1 çekirdek aile, 6's1 geniş aile yapısı içinde yaşamaktadır. Katılımcılardan 21'i yaşamının bir döneminde yaşlı bir birey ile aynı evi paylaşmıştır. Katılımcılardan 5'i ise yaşlı birey ile yaşamamıştır. Yaşlı birey ile aynı evde yaşayan 21 katılımcıdan 8'i 1 yıldan az, 3'ü 2-5 yıl arası, 1'i 6-10 yıl arası ve 9'u 11 yıldan daha fazla en az bir yaşlı ile yaşamıştır. Katılımcıların 16'sı yaşlı ile ilişkisini “çok iyi”, 6'sı "iyi” ve 4'ü "iyi değil” olarak tanımlamıştır. Katılımc1ların 13'ü aile çevresinde bulunan bir yaşlıyla "her gün", 10'u "haftada/on beş günde bir", 3'ü “ayda bir” görüştüğünü bildirmiştir. Katılımcıların 14'ü yaşlı bireyin çocuklarıyla aynı evde, 12'si yaşlı bireyin kendi evinde yaşaması gerektiğini düşünmektedir. Bu dağılıma göre katılımcılar arasında bakıma ihtiyaç duyan bir yaşlının ya kendi evinde ya da çocuklarının evinde bakılması gerektiği görüşü hâkimdir. Bu durum, çeşitli araştırmalarda da teyit edildiği üzere (Nazlıer-Keser, 2020; Türkiye İstatistik Enstitüsü (TÜİK), 2016) toplumsal değer yargıları ve ekonomik koşullar nedeniyle ortalama Türk Bireyinin henüz ‘kurumsal bakım’ fikrine yakın olmadığg şeklinde de yorumlanmaktadır.

\subsection{Araștırmanın Temaları}

Araştırmada katılımcıların kendi yaşlanmalarına yönelik algılarını ve yaşlılık algısını belirleyebilmek için iki ana tema ve 10 farklı alt tema belirlenmiştir. Bunlar; 
Tablo1. Temalar

\begin{tabular}{|c|c|}
\hline \multirow{3}{*}{$\begin{array}{l}\text { KENDİ YAŞLANMALARINA } \\
\text { YÖNELIK ALGILARI }\end{array}$} & Yaşlı Hissetme \\
\hline & Yaşlanmaktan Korkma \\
\hline & Dış Görünüşlerinde Ortaya Çıkan Değişikliklerden Rahatsız Olma \\
\hline \multirow{7}{*}{ GENEL YAŞLILIK ALGISI } & Yaşlı Kelimesinin Anlamı \\
\hline & Yaşlılık Yaş1 \\
\hline & Yaşlıların Giyim Tarzı \\
\hline & Yaşlıların Sosyal Yaşamı \\
\hline & Yaşlıların Üretkenlikleri \\
\hline & Bakıma Muhtaçlık \\
\hline & Yaşlılara Saygı Gösterme \\
\hline
\end{tabular}

\subsection{Katılımcıların Kendi Yaşlanmalarına Yönelik Algıları}

Yaşlanma algısı, yaşam boyunca şekillenen ve her bireyin benlik kavramının temelini oluşturan yaşam deneyimleri, eğitimleri, inançları, fikirleri, önyargıları ve toplumsal değer kalıplarının bir ürünüdür. Yaşlanma algısı sağlığın, yaşam kalitesinin ve hatta ölümlülüğün yordayıcıllğını içerir. Bireyin içinde olduğu yaşam döngüsü açısından yaşlılık en olumsuz özelliklere sahip bir süreç olarak da algılanılabilmektedir (Beja vd., 2018). Her bireyin kendi yaşlanmasına yönelik algıları, yaşlılara gösterilen özeni ve tutumları da etkileyebilmektedir. Bu nedenle katılımcılara, öncelikli olarak kendilerini yaşlı hissetme, yaşlanmaktan korkma ve dış görünüşlerinde ortaya çıkan değişikliklerden rahatsız olmaya yönelik sorular sorulmuştur.

\subsubsection{Yaşlı Hissetme}

Hissedilen yaş, kronolojik yaştan bağımsız olarak yaşlanmanın biyolojik, sosyal ve psikolojik belirtilerinden birisidir. $\mathrm{Bu}$ nedenle hissedilen yaşın bireye, kronolojik yaş ve yaşlanmayla ilgili algılarını etkileyerek, ona bir bakış açısı kazandırması açısından önemlidir. Bu bakış açısı, bireyin kendisini kaç yaşında hissettiği ve kendisini nasıl gördüğüne dair hem algısı hem de yargısı anlamına gelir (Kotter-Grühn vd., 2015; Sever ve Özgün Başıüyük, 2009).

Araştırmada katılımcılara "Herhangi bir insan kendini gerçekte olduğundan daha yaşlı veya genç hisseder”. Siz kendinizi çoğu zaman kaç yaşında hissediyorsunuz?” sorusu sorulduğunda, kat1lımcılar;

“Çoğu zaman ă̆ırlık çöküyor, yaşlanmış gibi oturaklaşmış gibi oluyorum. Nereden baksan 50 varım gibi görünüyor. Önceki gençliğim yok. Yaşlıları görünce yaşlı gibi oluyorum. 3-4 yıldır yaşlı gibi hissediyorum." (YB-2, Kadın, 45 yaşında),

"Genç hissetmiyorum. 45-50. Çok hasta olduğum için yaşlı hissediyorum.” (YB-5, Kadın, 20 yaşında),

"Bazen genç hissettiğim oluyor. Bazen yorgun, halsiz olduğumda yaşlı olarak hissediyorum. Neşeli olmakla ilgili.” (YB-23, Erkek, 40 yaşında). 
"Ben genç hissediyorum ama beni herkes yaşlı olarak görüyor o başka. Kendimi 24 yaşında hissediyorum." (YB-6, Kadın, 52 yaşında).

"Kendimi 18-20 yaşında hissediyorum." (YB-23, Erkek, 40 yaşında),

ifadelerinde de görüldüğü üzere bazı katılımcılar kendilerini kronolojik yaşına göre kendisini daha genç hissederken, bazı katılımcılar kronolojik yaşına göre daha yaşlı hissettiğini belirtmiştir. Bireylerin kendilerini kronolojik yaşlarına yönelik yaşlı hissetmelerinin nedenleri arasında fiziksel ve bilişsel işlev bozuklukları, beden gereksiniminden daha fazla beslenme gibi faktörler bulunmaktadır. (Stephan vd., 2016). Yapılan bir araştırmada bireylerin \%75'i kendisini kronolojik yaşa göre genç hissederken \%14'ü aynı yaşta, \%11'inin daha yaşlı hissettiği tespit edilmiştir (Thyagarajan vd., 2019).

\subsubsection{Yaşlanmaktan Korkma}

Yaşlanma, yaşam döngüsünün doğal bir süreci olmasına karşın bazı insanlarda yaşlanmaya yönelik korkular görülebilmektedir. Chasteen ve arkadaşlarının (2015) araştırmasında yaşlılık korkusunun yaş ile ilişkili olduğu ve yaş ilerledikçe bireyin daha yoğun yaşlanma korkusu yaşadığ1 belirlenmiştir. Chonody ve Teater (2016) araştırmasında katılımcıların yaşlanmaktan ve yaşlı görünmekten korktukları tespit edilmiştir.

Araştırmada katılımcılara "Yaşlanmaktan korkuyor musunuz?" sorusu yöneltildiğinde katılımcılar; "Yaşlıları gördükçe biz de o günlere geleceğimizi düşünüyorum. O yüzden korkmuyorum." (YB-20, Kadın, 26 yaşında), "Bu durum yaşamın bir süreci. Yaşamı tersine çeviremeyeceğimize göre yaşlılıktan korkmama gerek yok.” (YB-22, Erkek, 36 yaşında), “Korkmuyorum. Sonunda yaşlanacağız. Daha gencim. Önümde daha uzun yıllar var diye düşünüyorum” (YB-24, Kadın, 32 yaşında) şeklinde belirterek literatürden farklı bir şekilde katılımcıların çoğunun yaşlanmaktan korkmadığı görülmüştür. Bu durumun katılımcıların sosyo kültürel özellikleri ve modern toplumun ürettiği ‘beden' kavrayışına yönelik algıları ile ilişkili olduğu düşünülmektedir. Kültürel kodların etkisiyle şekillenen yaşl1lık hem biyolojik hem de toplumsal bir durumun yansımasıdır. Dolayısıyla yaşlanan bedenler, bedene ilişkin kültürel kodların, toplumsal algıların neler olduğuna dair ipuçlarını da içinde barındırmaktadır (Timurturkan ve Demez, 2018).

\subsubsection{Dış Görünüşlerinde Ortaya Çıkan Değişikliklerden Rahatsız Olma}

Önceden genç olarak nitelenen insanlar artık yaşlı olarak kabul edildikleri ve bedenlerinde bazı değişikliklerin (saçın beyazlaması, cildin kırışması gibi) ortaya çıkmasına bağlı olarak yaşlanmaya yönelik olumsuz tutumlar taşıyabilmektedirler. $\mathrm{Bu}$ durum araştırma kapsamında ele alındığında katılımcıların "Büyümüş ve olgunlaşmış oluyorum. Önceden bana bebek yüzlü derken buruşmuş gibi oldum." (YB-8, Kadın, 22 yaşında), "Sadece saçımda ak olmasından rahatsız oluyorum. Yaşlandı̆̆ımın farkına varıyorum." (YB-9, Kadın, 41 yaşında), "Yaşlı olmamda yüzümde ve gözümde kırışıklıklar oluşuyor. Artık genç olmadı̆̆ım için önemsemiyorum. Şimdiden sonra güzel olacağım diye bir şey yok." 
(YB-14, Kadın, 52 yaşında), "Kilo almaktan çok şikâyetçiyim. Kilo vermedikçe yaşımdan daha büyük gösteriyorum. Bu beni çok rahatsız ediyor. ”(YB-16, Kadın, 22 yaşında) ifadelerinde de görüldüğü üzere yaşın ilerlemesine bağlı olarak katılımcıların "saçın beyazlaması ve dökülmesi, kırışıklıkların artması" gibi dış görünüşlerinde ortaya çıkan değişikliklerden rahatsız olduklarını ifade etmiştir. Zira bedenin yaşlanmasının büyük bir trajedi olduğuna dair görüşler yalnızca günümüzde değil antik çağ Yunan ve orta çağ toplumlarında da görülmektedir. Antik Çağ Yunan toplumunda Juvenal'ın yazdığı hiciv metninde yaşl1lık 'buruşuk ve sarkık yüz', 'titrek ses ve uzuvlar', 'kel başlar ve sürüklenen burunlar', 'dişsiz diş etleri' gibi tanımlamalarla fiziksel görünüş öne çıkarılmıştır (Bertram, 1989). Orta çağ toplumlarında ise Roger Bacon (1214-92) yaşlılığın belirtilerini 'beyaz saç', 'solgunluk', 'cildin kırışması' olarak tasvir etmiştir (Shahar, 1998; Akınc1, 2020). Gerek antik çağ ve orta çağ toplumlarında gerekse modern toplumlarda yaşlanan beden, başarısızlık işareti olarak yorumlanmakta ve beraberinde bir yaşlanma kültürü sunarken bazı fırsatların da yok olduğu şeklinde yorumlanmaktadır (Higgs ve Jones, 2009).

\subsection{Genel Yaşlılık Algısı}

\subsubsection{Yaşlı Kelimesinin Anlamı}

Yaşl1 kelimesine verilen anlamlar zamana ve mekâna göre değişmekle birlikte bireyin sosyal ve kültürel ortamları ile yakından ilişkilidir. Literatürde yaşlı sözcüğü çoğunlukla başkasına bağımlılık, bakıma muhtaçlık ve yalnızlıkla ilişkilendirilmektedir (Ayalon, 2015; Viana Medeiros vd., 2016; Tufan, 2016). Bu araştırmada da literatüre benzer şekilde, katılımcılara; 'yaşl1' sözcüğünün akla getirdiği ifadelerin neler olduğu sorulduğunda çoğunlukla, bakım, bağımlılık, yalnızlık ve hatta çaresizlik ile ilişkilendirilebilecek sözler sarf ettikleri belirlenmiştir. Erkek katılımcıların kullandıkları sözcüklerden bazıları 'emeklilik' (YB-19, Erkek, 19 yaşında), 'yalnızlık' (YB-23, Erkek, 40 yaşında), 'düşkünlük' (YB-25, Erkek, 38 yaşında), kadınların ise 'bakım' (YB-3, Kadın, 21 yaşında), 'muhtaçlık' (YB-2, Kadın, 45 yaşında), 'yalnızlık' (YB-13, Kadın, 36 yaşında), ‘ömrün bitmesi’ (YB-1, Kadın, 57 yaşında), 'buruşuk' (YB-8, Kadın, 22 yaşında), 'yaşamış' (YB-20, Kadın, 26 yaşında), 'duygusallık' tır (YB-16, Kadın, 22 yaşında). Katılımcıların 'yaşlı' sözcügüne yönelik yüklediği olumsuz anlamlar yaşlılığa yönelik olumsuz algılarını da ortaya koymaktadır.

\subsubsection{Yaşlılık Yaşı}

Ülkemizde yaşlı nüfusun beklenen yaşam süresi 2019 yılı itibariyle ortalama olarak 78,3 yıldır. $\mathrm{Bu}$ yaş erkeklerde 75,6 ve kadınlarda 81 yıl olarak belirlenmiştir (TÜİK, 2020). Beklenen yaşam süresiyle ilgili bu oranlar, ileriye dönük projeksiyonlara göre daha da yükseleceği dikkate alınırsa, yaşlı kategorisine dâhil olan bireylerin toplum içerisinde gittikçe daha önemli bir yer edinebileceğini göstermektedir. Yaşlı nüfus oranının yüksekliği ise hangi yaş aralığının yaşlı olarak değerlendirileceği sorusunu karşımıza çıkarmaktadır. Yaşlılık için belirlenen yaş aralığı nesnel bir realite olmasına rağmen aslında bir algılama biçimidir. Dolayısıyla yaşlılık için belirlenen yaş, zamana ve toplumsal yapılara 
göre farklılıklar göstermektedir. Örneğin ilkel toplumlarda yaşl1lık yaşına çok az insanın ulaşabileceğine yönelik bir kabul söz konusudur ve yaşlılık dönemi, yaşama tutunmayı sağlayan kaynakların elde edilemediği bir süreç olarak görülmektedir. Antik çağ Yunan toplumlarında ise yaşl1lık hoşlanılmayan, acı veren, kasvetli, ölüme yakın bir dönem olarak ele alınmıştır. Orta çağ döneminde de 40'lı yaşların yaşlı sayıldığına dair bilgiler bulunmasına karşın o döneme ait yaş gruplandırmalarının 35, 45, 50, 58, 60, 72 olarak yapıldığına ve yaşı kategorisine 60 ve 70 yaşları arasında olanların dâhil edildiğine ve bu yaş grubuna yönelik bazı düzenlemelerin olduğuna dair bilgiler literatürde yer almaktadır (Shahar, 1998). Günümüzde ise yaşl1lık yaşıyla ilgili yapılan araştırmalarda farklı sonuçlara ulaşılmıştır. Türkbeyler ve diğerlerinin (2018) yaptığı bir araştırmada, katılımcıların yaşlılık başlangıç yaşı olarak

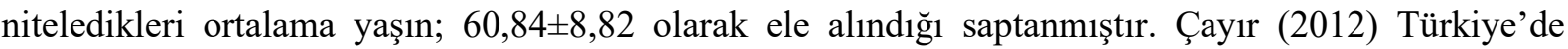
insanların 55 yaşından sonrasını yaşlılık dönemi olarak algıladığı tespitinden hareketle, Yunanlıların yaşl11ığın 68 yaşında başladığını düşünmelerini karşılaştırarak, aradaki farkın iki ülke arasında bulunan kültür ve algı farkından kaynaklandığını düşünmektedir. Bu araştırmada bir kadın katılımcı “Bence 30’u geçince yaşlı olunur. Otuzdan sonra kadınlar yaşını söylemek istemez. İnsan yıkılır.” (YB-15, Kadın, 23 yaşında) ifadesini kullanarak yaşlılık döneminin çok erken yaşta (30-40 yaşından sonra) başladığı görüşündedir. Başka kadın katılımcılar ise "70 yaşında. Çünkü annem 65 yaşında, kayınvalidem 70 gibi. Annem kayınvalideme göre daha aktif. Kayınvalidem 70 yaşına gelince bakıma muhtaç oldu” (YB-9, Kadın, 41 yaşında), "Yaşla alakası yok. Hayattan bıkkın, küskün olanlar yaşlı hisseder." (YB-13, Kadın, 36 yaşında) şeklinde belirterek yaşlılığın yaş ile tanımlanmaması gerektiğini, kişi kendisini yaşlı hissettiğinde ve bakıma muhtaç olduğunda yaşlılık döneminin başladığını ifade etmişlerdir. Bir erkek katılımcı ise "Emekli olduğunda. Çalışacak işi olmadiğı için verimden düşer ve kendini yaşlı hisseder." (YB-23, Erkek, 40 yaşında) diyerek yaşlı bireylerin gücü ve enerjisi azaldığında, güçten düştüğünde ve emeklilik durumunda yaşlı sayılabileceğini belirtmiştir.

\subsubsection{Yașlıların Giyim Tarzı}

Giyinmek bireylerin fizyolojik ve psikolojik ihtiyaçlarını karşılamanın yanı sıra bir topluma ait olma hissini ve kimlik duygusunun oluşmasını sağlamaktadır (Kaçar, 2019). Giyim tarzı bireylerin yaşı, zevkleri, ilgi alanları, statüsü, karakteri gibi bazı özellikleri hakkında önemli bilgiler vermektedir. Yaşlanmayla beraber ortaya çıkan fiziksel değişimler nedeniyle yaşlı bireylerin giyim tarzı fizyolojik, anatomik, psikolojik ve sosyal özelliklerden etkilenmektedir (Kaçar, 2019). Yaşlıların giyim tarzlarına yönelik çeşitli araştırmalar yapılmıştır. Gürşahbaz ve arkadaşları (2009), yaşlı kadınların rahat ve vücutlarına uygun, kullanışlı giysileri öncelikle tercih ettiklerini belirlemiştir. Kaçar (2019, ss. 55-56) yaşlı kadınların rahat kullanabilecekleri, kolay giyip çıkartabilecekleri, yaşına uygun, sade kıyafetleri tercih ettiklerini tespit etmiştir. Bu araştırmada ise literatüre benzer şekilde katılımcıların bazıları "Yaşlı bireyler nasıl giyinmelidir" sorusu üzerine görüşleri ele alındığında; "Podyuma çıkar gibi giyinmemeli. Ama kişisel bakıma kılık kıyafete dikkat etmelidir." (YB-3, Kadın, 21 yaşında), "Kahverengi ve gri tonda giyinmelidir. Cirtlak renkler kırmızı gibi yaşlıya hayatta yakışmaz.” (YB-26, Kadın, 20 yaşında), 
“Şık giyinmelidirler. Açık renk giyilmelidir. Yaşından genç giyinirlerse psikolojik olarak kendilerini iyi hissederler." (YB-17, Kadın, 27 yaşında) diyerek yaşlı bireylerin yaşına uygun ve rahat edebileceği kıyafetler giymesi gerektiğini, onları genç gösterecek şık giyim tarzının olması gerektiğini savunmuştur.

\subsubsection{Yaşlıların Sosyal Yaşamı}

Yaşlılar hem kendi yaş grupları hem de diğer yaş grupları içerisinde sosyal çevreye uyum sağlamak, toplumsal ilişki kurabilmek, bireysel fikirlerini hür bir biçimde dile getirebilmek ve kendi öz benliklerini yansıtabilmek için çeşitli sosyal ortamlara ihtiyaç duymaktadırlar (Özkul vd., 2019). Yaşlılar formel (hükümet, sağlık hizmeti sağlayıcıları ve/veya diğer kuruluşlarla vb.) ve enformel (aile, arkadaşlar, komşular gibi) toplumsal ilişkiler geliştirebilmektedirler (Canatan, 2016). Yaşlıların sosyal etkileşimlerde bulunması, formel veya enformel toplumsal etkinliklere dâhil olması, benlik ve özgüven duygusunu pekiştirmekte, onların mutlu, umutlu olmalarını sağlamaktadır (Kalınkara, 2011). Kim ve Lee (2018) araştırmalarında yaşlıların sürdürdükleri sosyal ilişkilerin yaşam kaliteleri ve sağlıkları üzerine olumlu etkileri olduğunu bildirmektedirler.

Bu araştırmada katılımcılara "Yaşlılar sosyal hayata dâhil olabiliyor mu?" sorusu sorulduğunda 18 katılımcı yaşlıların sosyal ilişkilerini sürdürdüklerini ve 21 katılımcı ise yeni arkadaş edinebildiklerini ifade etmişlerdir. Buna göre, bazı katılımcıların "Yaşlılar kapının önüne oturduklarında tüm mahalleyi başına toplayabiliyorlar. Bence yaşlının yalnız kalması, az kişinin ziyaret etmesiyle, ailenin ilgisizliği ile alakalıdır." (YB-25, Erkek, 38 yaşında), "Yaşlılar bazen çocuklaşır, bazen olgunlaşır. O nedenle herkesle arkadaş olabilir." (YB-26, Kadın, 20 yaşında) ve "Konuşmadan konuşmaya fark eder. Kimisi kendi beğenmişçesine konuşur kimi de daha tatlı konuşur ve arkadaş edinir. ” (YB-20, Kadın, 26 yaşında) ifadelerinden de anlaşılacağı üzere yaşlı bireylerin aile, arkadaş, komşu gibi enformel toplumsal ilişkiler geliştirebildiklerini belirtmişlerdir. Ancak bazı yaşlı bireyler sosyal yaşama katılımda engellerle karşılaşabilmektedir. Literatürde yaşlıların sosyal yaşama dâhil olmamasının nedenleri; yalnız yaşaması, yakın akrabasının bulunmaması veya aile üyeleriyle arasındaki coğrafi mesafenin fazla olması, diğer bireylerle görüşmemesi, evinden çıkamaması, hasta olması, engeli olması, sosyal ilişkilerin az olması, sosyal entegrasyonu destekleyecek ulaşım ve tesislerin eksikliği gibi unsurlarla açıklanmaktadır (Breheny ve Severinsen, 2018; El Haj vd., 2016). Bu araştırmada ise literatüre benzer şekilde katılımcılar "Zor. Yürüyemedikleri için evden çıkamıyorlar ve insan yüzü göremiyorlar. O yüzden arkadaşlık kuramıyorlar." (YB-5, Kadın, 20 yaşında), "Yaşlanınca dışarı çıkmaları kolay olmuyor. Dışarı çıkamayınca kimseyle iletişsim kuramaz.” (YB-21, Kadın, 25 yaşında) ya da "Yaşlılıktan dolayı zor arkadaş edinirler. Bulaşıcı hastalı̆̆ varsa insanlar onlardan kaçar." (YB19, Erkek, 19 yaşında), "Hasta oldukları için, yatağa bağlı oldukları için arkadaş edinemezler." (YB11, Kadın, 28 yaşında) şeklinde belirterek yaşlıların sosyal yaşama dâhil olmama nedenlerini; yaşlı bireylerin "yürüyememesi, evden çıkamaması, hasta olması ve kaybolma riski" olarak sıralamışlardır. 
Yaşlıların sosyal etkileşime geçtikleri bireyler, yaş özellikleri bakımından farklılık göstermektedir. Bazı yaşlılar akranları ile birlikte olmayı tercih ederken bazı yaşlılar kendilerinden daha genç yaşta olan bireylerle vakit geçirmektedirler. Örneğin Mathur (2015) yaşlı erkeklerin benzer yaş grubunda bulunan bireylerle iletişime geçtĭgini, yaşlı kadınların aile üyeleri, akrabalar, arkadaşlar, komşular gibi akranları ve daha gençlerle sosyal ilişkilerini sürdürmeye çalıştıklarını bildirmektedir. $\mathrm{Bu}$ araştırmada da katılımcıların çoğu "Herkesle arkadaş olabilir. Daha genç birinden bile fayda görebilir. Kayınvalidem, annem torunları gelince çok mutlu olur." (YB-9, Kadın, 41 yaşında), "Yaşlılar gençlerle arkadaş olabilirler. 19 yaşındakiler 19 yaşındakilerle, 80 yaşındakiler 80 yaşındakilerle arkadaş olacaksa ve 80 yaşındakinin yaşıtı hayatta değilse o insanı yalnızlı̆̆a mı bırakacağız o zaman." (YB17, Kadın, 27 yaşında), “Her yaşlı 7'den 70'e herkesle sohbet etmeli, hayatı bırakmamalı. Yoksa onları topră̆a koy gitsin." (YB-19, Erkek, 19 yaşında) şeklinde belirttikleri görüşler doğrultusunda yaşl1 bireylerin gençlerle birlikte olmaktan mutlu olduklarını düşündüklerini bildirmiştir. Buna karşılık bir katılımeı "Gençler yaşlının derdini anlayamaz ve aralarında iletişim kopukluğu olur. Bu nedenle yaşlılar mutsuz olur." (YB-23, Erkek, 40 yaşında) ifadesini kullanarak yaşlı bireylerin gençlerle birlikte olmaktan mutlu olamayacağını, yaşa bağgl olarak aralarında iletişim kopukluğu olacağını ifade ederek yaşa dayalı bir ayrımcılık yapmıştır.

Diğer yandan bazı katılımcılar "Gençler yaşlıların çok konuştuklarını düşünürler." (YB-6, Kadın, 52 yaşında), “Gençler yaşlıların yanında olmak istemezler ve onlara kötü davranabilirler.” YB7, Kadın, 19 yaşında), “Gençler yaşlılara tahammül edemezler.” (YB-24, Kadın, 32 yaşında) diyerek gençlerin yaşlılarla birlikte vakit geçirmekten hoşlanmadıklarını, yaşlı bireylerin "Sosyal biri olamadıkları ve yeniliklere açık olamadıkları için kendi yaş grubuyla daha iyi anlaşırlar. Diğer kişilerle aynı konuyu konuşamazlar bile.” (YB-18, Kadın, 19 yaşında), "Yaşlı yaşlıyla konuşmalıdır.” (YB-24, Kadın, 32 yaşında) şeklinde de görüldüğü üzere kendi yaşıtlarıyla birlikte daha mutlu olduklarını ve daha iyi iletişim kurabildiklerini ifade etmişlerdir. Ancak bazı katılımcılar ise tam tersi bir şekilde "Sağına soluna baksa yaşlı görünce mutsuz olur. Gençlerle birlikte olsa civll clvıl olsun. 70-80 yaşındakiler cıvıl cıvıl olmaz." (YB-14, Kadın, 52 yaşında), "Yaşlının içi geçmemişse kendi yaş grubuyla birlikte olmamalıdır. Bu yaşlının karakteriyle ilgili." (YB-16, Kadın, 22 yaşında) ifadelerine yer vererek yaşlıların sadece kendi yaş grubuyla birlikte olmasını uygun görmediklerini, bu durumun yaşı bireyleri mutsuz edeceğini belirtmişlerdir.

\subsubsection{Yaşlıların Üretkenlikleri}

Yaşl1lık kuramlarından birisi olan "Etkinlik Kuramı", yaşlanma sürecini kaliteli bir şekilde geçirmeleri için bireylerin yaşamını aktif şekilde sürdürmesi gerektiğine odaklanmaktadır (Kalaycı ve Özkul, 2018). Bu çerçeveden bakıldığında üretkenliklerini sürdürebilen yaşlılar, yaşamında daha huzurlu ve mutlu olabilmektedirler. Yaşlılarda üretkenlik, ev işleri, çocuk bakımı, gönüllü çalışma, ailesine ve arkadaşlarına yardım gibi faaliyetler de dâhil olmak üzere, ücretli olsun ya da olmasın, mal 
veya hizmet üretilen herhangi bir faaliyet olarak tanımlanmaktadır. Yaşlıların üretkenliği, şimdiye kadar ekonomik yaşama odaklanmasına karşın günümüzde sosyal yaşamda ürettikleri hizmeti de kapsamaktadır. Bireyler iş gücü yaşamına önemli katkılar sağladıktan sonra, yaşlılık döneminde gerek ev yaşamlarına gerekse sosyal ilişkilerine önemli katkılar sağlamaya devam etmektedirler (FernándezBallesteros vd., 2011). Literatürde yaşl1lık döneminde üretkenliğin sürdürülmesi halinde; yaşlı bireylerin bağımsızlıklarını devam ettirme, fiziksel ve mental sağlık düzeylerini geliştirme imkânı buldukları da bildirilmektedir (Penninx vd., 2001; Salar vd., 2016). Yaşlı bireyler mal ve hizmet üretmek (ücretli ve ücretsiz), ailesine her alanda yardımcı olmak, çocuk bakma sorumluluğunu üstlenmek, aile gelirini düzenleme konusunda çocuklarına fikir sunmak, ev içi işleri yapmak, üretim faaliyetine aktif olarak katılmak, dinsel ve törensel konularda rehberlik etmek, aile içinde ilişkileri düzenlemek vb. gibi üretkenlik içeren faaliyetlerde yer alabilmekte ve kendilerini üretken, yaratıcı ve işe yarar hissedebilmektedirler (Feng vd., 2020). Kore'de 65 yaş ve üstü bireylerle yapılan bir araştırmada yaşlıların \%14,2'si ücretli bir işte çalışırken \%84,8'i ücret almadan ev içi sorumluluklarını yerine getirdikleri belirlenmiştir (Kim, 2019). İspanya'da yaşlıların yer aldığı ücretsiz ev işlerinin ekonomi üzerine önemli katkı sağladığı tespit edilmiştir (Fernández-Ballesteros vd., 2011). Bu araştırmada ise bazı katılımcılar "Evde olan her işi yapmalı. Başka ne iş yapabilir ki. Kadın ne iş yapabilir ki. Namaz kılar, torunlara bakar. Kendine dikkat etmesi, araba çarpmamasl, yolun kenarından gitmesi gerekir." (YB-1, Kadın, 57 yaşında), "Kenarda oturmalı, torunlarına el öptürmesi lazım. Çantasını koluna alıp işe gitmemeli. Örgü örmeli. Evi temizlemeli. Erkekler iğneyle tespih çizmeli.” (YB-8, Kadın, 22 yaşında) şeklinde belirterek yaşlı bireylerin ev içerisinde yapması gereken faaliyetleri aileyi yönetmek, ev işi/el işi yapmak, kendi kişisel bakımlarını yapmak, torun bakmak olduklarını belirtmektedir. Buna karşılık bazı katılımcılar yaşlı bireylerin ev içindeki belli başlı sorumluluklarına yönelik "Sorumlulukları yoktur. Yesinler, içsinler, dinlensinler, namazını kılsınlar." (YB-25, Erkek, 38 yaşında), "İş yapmamalı, sadece çocuğunu, torununu yönetmelidir." (YB-19, Erkek, 19 yaşında) şeklinde görüş bildirerek yaşlı bireylerin ev içerisinde herhangi bir sorumluluğu olmadığını düşünmektedir.

Yaşlıların ev dışındaki sorumluluklarını ise "Aynı evde yaşıyorsa alışveriş yapmalı, fatura ödemeli. Yardımcı olunca oğlu mutlu olur.” (YB-3, Kadın, 21 yaşında) ifadesinde de belirtildiği üzere alışveriş yapmak ve fatura ödemek olarak sınırlarken, bazı katılımcılar " $E v$ dişında bir sorumluluğu yoktur.” (YB-20, Kadın, 26 yaşında), "Sadece gezebilir. Başka iş yapamaz ki." (YB-14, Kadın, 52 yaşında), yaşlı bireylerin ev dışında herhangi bir sorumluluğu olmadığını düşünmektedir. Buna göre katılımcıların önemli bir kısmı yaşlı bireylerin ev dışında sorumluluğunun olmadığını düşünmesi yaşlıları üretken olarak görmemesi ile ilişkilendirilebilir.

Avrupa'da ve Japonya'da emeklilik yaşının daha ileri yaşa yükseltilmesi ile yaşlıların işgücü piyasasına katılım oranı artmıştır. Özellikle işverenlerin tecrübeli ve vasıflı elemanlarla çalışma talebi yaşl1ların işgücünde yer almasını desteklemektedir (Blomé vd., 2020). Ancak ülkemizde yaşlılar işgücü piyasasında yer bulmakta zorluk yaşamaktadırlar (TÜİK, 2016). Kalaycı ve Özkul'un araştırmasında 
(2017) yaşlıların çok az bir kısmının işgücü piyasasında kendine yer bulabildikleri belirlenmiştir. Literatürde işgücü piyasasında yer alan gençlere ve yaşlılara yönelik farklı görüşler hâkimdir. Yaşlıların gençlere göre işine sadık olduğu, yönetimsel ve kişilerarası becerilere, yaratıcı problem çözme kapasitesine sahip olduğu, ama teknolojiye uyum sağlayamadığı bildirilmektedir. Gençlerin ise yaşlılara göre teknolojiye uyum sağladığı, verimli olduğu, esnek çalışma saatlerine uyum sağladıkları belirlenmiştir (Blomé vd., 2020).

"Çalışmasalar daha iyi. Bunca yıl çalışmışlar dinlensinler. Teyzenin kocası erken ölmüş. Tarla işi yaparken çocuklara bakmış. Artık dinlenmesi lazım. Çocuklarının ona bakması lazım." (YB-2, Kadın, 45 yaşında)

“İşsizlik zaten büyük sorun. Yaşlılar çalışmış çalıştı̆̆ kadar. Yerini gençlere vermeli. Gençler üniversite okuyor. Daha dikkatli oluyor.” (YB-3, Kadın, 21 yaşında)

“Genç yaşlarda çalışmışlardır. Yaşlanınca artık oturup maaşlarını yemelidir.” (YB-21, Kadın, 25 yaşında)

"Yaşlılar hayatlarını yaşamışlar. Gençlere sıra verilmelidir. Çünkü işsizlik büyük sorun."(YB18, Kadın, 19 yaşında)

Yukarıdaki ifadelerden de anlaşılacağı üzere bu araştırmada ise 20 katılımcı, yaşlıların, gençlerin istihdamını olumsuz etkileyeceği gerekçesi ile iş hayatında yer almaması gerektiğini düşünmektedir. $\mathrm{Bu}$ nedenle eğer yaşlılar çalışacaksa ev işi/el işi, bahçe işi gibi bedenen ve ruhen yorulmayacakları ve gençlerin iş bulmalarını engellemeyecek işlerde çalışmaları gerektiğine inandıklarını ifade etmişlerdir. Ayrıca katılımcıların "Çalışma yaşamında bireyler arasındaki terfilerde yaşlılardan ziyade gençlere öncelik verilmesi gerektiğini düşünüyor musunuz?" sorusuna yönelik görüşleri ele alındığında "Müdür genç olur. Yaşlılara verilmez. Yaşlıların aklı gençler kadar mı? Gençler daha akıllı." (YB-4, Kadın, 45 yaşında), "Yaşlı sonuçta onlar. Az biraz daha yaşayacak, sonra yaşamayacaklar. Gençler daha uzun yaşayacaklar." (YB-12, Kadın, 45 yaşında), "Hak edene verilmelidir. Yaş terfide kriter olmamalı. Gence ve işin akışına haksızlık olur.” (YB-22, Erkek, 36 yaşında) şeklindeki ifadelerde de dile getirildiği üzere katılımcılar aynı iş ortamını paylaşan genç ve yaşlıların terfi alması gerektiğinde terfiyi genç çalışanın alması gerektiğini, yaşlı çalışanın emekli olmasının önemli olduğunu belirtmişlerdir.

\subsubsection{Bakıma Muhtaçlık}

Yaşlı bireyin toplum içerisinde bağımsız yaşayabilmesi için öncelikle temel gereksinimlerini karşılaması, sonrasında günlük ve enstrümantal yaşam aktivitelerini yerine getirebilmesi gerekir. Bireyler ortaya çıkan hastalık ve yetersizlik durumunda, temel insan gereksinimlerini ve enstrümantal yaşam aktivitelerini karşılayamamaktadır (Özbek Yazıcı ve Kalaycı, 2015; Kalaycı ve Çelikkol, 2014). Günlük ve enstrümantal yaşam aktivitelerini yerine getiremeyen yaşlılar bakıma muhtaç hale gelmekte 
ve diğer bireylere/kurumlara bağımlılığ artmaktadır. $\mathrm{Bu}$ araştırmada katılımcılar "Kendi işsini yapamayanlar.” (YB-6, Kadın, 52 yaşında), "Elden ayaktan düştüyse bakıma muhtaçlıktır.” (YB-10, Kadın, 37 yaşında), "Kendi işini, yemeğini, temizliğini yapamamak.” (YB-12, Kadın, 45 yaşında), "Elden ayaktan düşmek, kendi ihtiyaçlarını karşılayamamak." (YB-25, Erkek, 38 yaşında) şeklindeki ifadeleriyle bakıma muhtaç yaşlıları "kendi bakımını ve işini yapamayan, düşkün ve yatağa bağımlı" kişiler olarak tanımlamıştır.

Yaşlıların fiziksel, duygusal ve bilişsel sağlık sorunlarına yönelik; öncelikle aile üyeleri ve akrabaları olmak üzere, arkadaşları, komşuları gibi diğer yakınları için bakım verme sorumluluğu ortaya çıkmaktadır. Bakım verme sorumluluğu, hemen her kültürde öncelikle eş ve çocuklar tarafından üstlenilmekte ve aile içi bir görev olarak kabul edilmektedir (Kalınkara ve Kalaycı, 2017). Literatürde bakım desteğinin sıklıkla aile üyelerinden ve diğer yakınlardan alındığı, en fazla yaşlı eşlerinin bakım sorumluluğunu üstlendiği $(\% 30,6)$ (Bertogg ve Strauss, 2020; Fee vd., 2019) bildirilmiştir. Araştırmada katılımcılardan 19'u yaşlının bakımını çocuklarının, 4'ü bakıcıların ve 3'ü kurumların yapması gerektiğini ifade etmiştir. Buna göre katılımcıların "Yaşlı bakım evlerinden yardım alabilirler." (YB16, Kadın, 22 yaşında), "En başta kendisinden biri, o yoksa sonra ailesinden biri o da yoksa devletten biri bakmalıdır." (YB-23, Erkek, 40 yaşında), "Kızları, evlatları bakmalıdır." (YB-24, Kadın, 32 yaşında), "Evlatları varsa evlatları bakmalıdır. Evladı yoksa hemşire veya hasta bakıcı tutulmalıdır." (YB-26, Kadın, 20 yaşında) ifadelerinde de görüldüğü üzere hemen hemen bütün yaş grupları açısından kurumsal bakım tercihine göre ve çok büyük bir farkla yaşlının ya kendi evinde ya da çocuklarının evinde bakımının yapılması gerektiğini belirtmektedirler. Görüşülenlerin sadece eğitim düzeyi ve ekonomik gelir düzeyi birlikte yükseldiğinde kurumsal bakım fikrine yönelik bir eğilim az da olsa görülmektedir. Ancak her halükârda kurumsal bakım tercihi deneklerin tamamına yakını açısından son tercih olarak belirlenmiştir. Bu durum aynı değer hükümlerini taşıyan toplumsal çevrenin baskısı mıdır? Yoksa yaşlıların ya da bakımını üstlenecek yakınlarının gelir düzeylerinin düşüklüğüyle mi? ilgili olduğu ayrıca araştırılması gereken bir husus gibi görünmektedir.

Yaşlı bakımında bakım verenler yaşlı bireyin günlük yaşam aktivitelerine (vücut bakımının yapılması, giydirilmesi, beslenmesinin sağlanması, boşaltımının yapılması gibi) ve günlük yaşamın enstrümantal aktivitelerine (yemek hazırlama, alışveriş yapma, para idaresini yapma, çamaşır yıkama, ev işlerini yapma, telefon kullanma, ilaçlarını verme gibi) yönelik ihtiyaçlarını karşılamaktadır (Wolff vd., 2016). Araştırmada katılımcılara "Bakıma muhtaç yaşlıların bakımında neler yapılmalıdır?” sorusu sorulduğunda "Tüm işleri yapılmalıdır." (YB-4, Kadın, 45 yaşında), "Yatalakların banyosu yaptırılmall, yemek yedirilmelidir.” (YB-5, Kadın, 20 yaşında), “Günlük bakımı yapılmalı. İlaçlarına dikkat etmeli, zamanında verilmeli, vücut temizliği yapılmalıdır." (YB-13, Kadın, 36 yaşında), "Her ihtiyacı karşılanmalıdır." (YB-21, Kadın, 25 yaşında) şeklindeki ifadelerinde görüşülenler, yaşlı bakımında vücut temizliğini yapmanın, yemek yedirmenin, ilaçlarını içirmenin, yara bakımını yapmanın önemli olduğunu vurgulamışlardır. Ayrıca katılımcılar "Yaşlılar her konuda ev işinde, sağlıkta, her 
konuda deneyimlidir. Onlara her şey sorulmalıdır. Belli konularda fikir alınmalıdır. Her şeyi bilirler." (YB-11, Kadın, 28 yaşında), "Üzmemeli." (YB-11, Kadın, 28 yaşında), "Mahremiyetine dikkat edilmeli." (YB-13, Kadın, 36 yaşında), "Narin davranılmalı." (YB-16, Kadın, 22 yaşında), "Güler yüzlü, itip kalkmadan, nefret ettirmemek, korkutmamak gerekir." (YB-24, Kadın, 32 yaşında) şeklinde belirterek yaşlı bakımıyla ilgilenenlerin, bakım sürecinde yaşlıya karşı güler yüzlü ve nazik olmanın, mahremiyete önem vermenin, yaşlının fikirlerine ve önerilerine saygı göstermenin gerekli olduğunu ifade etmişlerdir.

\subsubsection{Yaşlılara Saygı Gösterme}

Bireylerin yaşlanmaya ve yaşlı bireylere yönelik algıları çoğunlukla sosyal çevrenin etkisinden kaynaklanmakta, bu etki olumlu veya olumsuz yönde olabilmektedir. Yaşlanmaya ve yaşlı bireylere yönelik olumsuz algılar yaşl1lara karşı saygısızlık gösterilmesine, olumlu algılar ise yaşlı insanlara saygı gösterilmesine neden olabilir. Örneğin, yaşlı insanlara saygı duyulan sosyal bir çevrede yaşayan birey, yaşl1lığa ilişkin olumlu beklentiler geliştirme eğiliminde olmaktadır (Malik vd., 2016). Ülkemizde çekirdek aileye dönüşümün olması kolektivist bir toplumdan bireyci bir topluma doğru geçişin de bir göstergesidir. Bu durum aile içerisinde bulunan çocukların ve gençlerin, yaşlı olan büyükanne ve büyük babalarıyla görüşme sıklı̆̆ının azalmasına neden olmuştur. Sosyal mekânların farklılaşması, fiziksel mesafelerin artması nedeniyle ilişkilerin seyrelmesi yaşlılara gösterilen saygı ve ilgilenme davranışının da değişmesine neden olmuştur. Örneğin yaşlı bireye yardım etmek, onu görünce ayağa kalkmak ve yer vermek, göz teması kurmak gibi örnekler günümüzde gençler tarafından gittikçe daha az temsil edilir hale gelmiş davranışlar arasındadır. Öte yandan geleneksel değerlerin gündelik hayatta hala baskın olduğu ülkelerden biri olan Pakistan'da yapılan bir araştırmada katılımcıların \%84,8'i tarafından yaşlılara yüksek düzeyde saygı gösterildiği tespit edilmiştir (Malik vd., 2016). Bu araştırmada da katılımcılara "Sizce yaşlılara gereken saygı ve özen gösteriliyor mu?" sorusu sorulduğunda katılımcıların "Gençler yaşlıları görünce hemen ayağa kalklyorlar ve onlara saygı gösteriyorlar." (YB1, Kadın, 57 yaşında), “Annesi ve babasına göstermesi gereken sevgiyi saygıyı gösterirler. Yaşlılar tecrübelidir." (YB-7, Kadın, 19 yaşında), "Çoğu aile biz de yaşlanacağımız için saygı gösterir. Belli konularda fikirleri alınır." (YB-21, Kadın, 28 yaşında) ve "Yaşlılar ev işinde, sağlıkta, her konuda deneyimlidir. O yüzden onlara herkes saygı gösterir." (YB-14, Kadın, 52 yaşında) ifadelerinden de anlaşılacağı üzere kendi aile üyelerinin yaşlılara "yaşlarından dolayı onları görünce ayağa kalkmak, belli konularda onların fikirlerini almak" gibi davranış ve hareketlerde bulunarak onlara saygılı davrandıklarını ifade etmişlerdir.

\section{SONUÇ}

Dünyada doğurganlık oranlarının azalması ve insan ömrünün uzamasıyla birlikte yaşlı nüfusunun artması, değişen birçok toplumsal, ekonomik, teknolojik koşullarla birlikte yaşlılık algısına yeni boyutlar kazandırmaktadır. Yaşlanma her birey için kaçınılmaz bir süreçtir. Ancak yaşa ve yaşlılığa 
yüklenilen anlam ve değer toplumdan topluma değişiklik göstermektedir. Özellikle bir toplumda sosyal ve kültürel özellikler göz önüne alındığında yaşa ilişkin olarak geliştirilen toplumsal normlar ve kalıp yargılar yaşlılığın anlamını ve yaşlılık algısını değiştirmektedir. Daha önce de belirtildiği gibi araştırmada katılımcıların kendi yaşlanmalarına yönelik algıları ve genel yaşlılık algıları olmak üzere iki kavramsal tema üzerinde durulmuştur.

Katılımcıların kendi yaşlanmalarına yönelik algılarında; "yaşlı hissetme, yaşlanmaktan korkma, dış görünüşlerinde ortaya çıkan değişikliklerden rahatsız olma" temalarına yer verilmiştir. Bu temalar çerçevesinde tasnif edilen verilere göre katılımcıların büyük bir kısmı yaşlılıktan korkmadıklarını dile getirmektedirler. Ancak katılımcılardan görece ileri yaşta olanların yaşın ilerlemesiyle birlikte fiziksel ve bedensel olarak dış görünüşlerinde ortaya çıkan değişikliklerden rahatsızlık duydukları tespit edilmiştir. Bu durum her şeyden önce 'yaşlı' nitelendirmesinin fiziksel ve bedensel görünümdeki değişiklik üzerine temellendirildiğini göstermektedir.

Araştırmada aynı zamanda "yaşlılık kelimesinin anlamı, yaşlılık yaşı, yaşlıların giyim tarzı, yaşlıların sosyal yaşamı, yaşlıların üretkenlikleri, bakıma muhtaçlık ve yaşlılara saygı gösterme" temaları çerçevesinde yaşı ıakım istihdamında yer almak isteyen katılımcıların genel yaşlılık algıları değerlendirilmiştir. Buna göre katılımcılar "emeklilik, düşkünlük, muhtaçlık, yalnızlık, ömrün bitmesi” gibi kavramlara yer vererek yaşlı kelimesine ve yaşlılık dönemine olumsuz anlamlar yüklemektedir. Özellikle kadın katılımcılar tarafından yaşlı1ık döneminin çok erken yaşta başladığı belirtilerek, kişinin kendisini yaşlı hissetmesi, kendi ihtiyaçlarını karşılayamaması ve bakıma muhtaç duruma gelmesiyle birlikte yaşlılık döneminin başladığı ifade edilmektedir. Ayrıca katılımcılar gündelik yaşamlarında yaşlı bireylerin rahat edebileceği kıyafetler giymeleri ve toplumsal alanda sosyal ilişkilerini sürdürmeleri gerektiğini belirtmektedir.

Sosyal yaşama dâhil olmama nedenleri olarak ise katılımcılar, yaşlı bireylerin "evden çıkamama, hasta olma ve kaybolma" gibi durumlarını belirterek bakıma muhtaç durumda olan yaşlıların yalnızlık sorununa ve yaşam kalitesinin düşüklüğüne vurgu yapmaktadırlar. Yaşlı bireylerin yaşamını aktif bir şekilde sürdürebilmeleri için ise "ev işleri, çocuk bakımı, aile içi ilişkileri yönetme" gibi faaliyetleri yerine getirerek üretkenliklerini devam ettirebileceklerini belirtmektedirler. Aynı zamanda katılımcılar gündelik yaşam pratiklerini yerine getiremeyen yaşlıların aile üyelerine ya da bakım hizmeti veren bireylere/kurumlara olan ihtiyaçlarının arttığını ifade etmektedir. Buna göre katılımcılar bakıma muhtaç durumda olan yaşlı bireyleri, kendi yemek ihtiyaçlarını karşılayamayan ve kendi öz bakımını yapamayan, düşkün ve yatağa bağlı kişiler olarak tanımlamaktadır.

Yaşlı bakım istihdamında yer almak isteyen katılımcıların yaşlanma algılarındaki bireysel farkl11ıklar da göz önünde tutularak yaşlı bireylere, yaşl1lık dönemine olumsuz anlamlar yüklemekte ve yaşl11ık sürecini "muhtaç olma, düşkün olma" gibi kavramsallaştırmalar noktasında değerlendirmektedir. Ancak yaşlı bakım istihdamında yer almak isteyen bireylerin bu olumsuz 
tutumları, belirli bilgi ve becerilerinin yanı sıra, çeşitli görevlerin uygulanması ve deneyim kazanılmasıyla değiştirilebilir. Bu doğrultuda yaşlanma algısına yönelik olumsuz tutum ve değerleri değiştirmeye ve onu daha olumlu hale getirmeye odaklanan müdahalelerin geliştirilmesi özellikle önemlidir. Dolayısıyla burada meslekle ilgili etik değerlerin belirlenmesi ve eğitim süreçlerinde bu değerlere uygun davranışların neler olduğuna ve nasıl üretileceğine yönelik bilgi ve alışkanlıkların kazandırılması gerekmektedir. Bu noktada Durkheim'in 'meslek ahlakı' hatırlanacak olursa; modernleşme sürecinde değişen ve farklılaşan toplumun ahlaki bütünlüğünü kazanmasında en önemli kaynak meslekler yoluyla oluşturulan denetim mekanizmasıdır (Durkheim, 1962). Buna göre araştırmada yaşlı bakım istihdamında yer almak isteyen bireylerin daha çok geleneksel değerleri kaynak alması, bakım personeli yetiştirilmesine yönelik eğitim süreçlerinin yetersizliğine işaret eden bir husustur. Bu nedenle yaşlı bakımına yönelik personel eğitiminde kullanılan müfredatın geliştirilmesi, eğitim veren personelin alanında uzman olması, uygulamalı eğitimlerin yapılması (yaşlı bireylerin bakım gereksinimlerine yönelik yaşı hasta maketinin, hasta bakım malzemelerinin vb. kullanılması) ve alanında uzman gözetmenler eşliğinde kurumlarda yaşlılarla birebir çalışılmasına olanak sağlanması gibi hususların dikkate alınması gerekmektedir.

\section{KAYNAKÇA}

Akınc1, A. Y. (2020). Antikçağdan Moderniteye Gerontolojinin Doğuşu. Deniz Say Şahin (Ed.). Etik Yönleriyle Yaşlılık ve Yaşlanma içinde (1-32). Bursa: Ekin Yayınları.

Ayalon, L. (2015). Perceptions of old age and aging in the continuing care retirement community. International Psychogeriatrics, 27(4), 611-620. doi: $10.1017 / \mathrm{S} 1041610214002415$

Beja, M. J., Franco, G., Sousa, J. M., Candeias, A. A. ve Aveiro, S. (2018). Ageing perception in seniors' formal caregivers. MOJ Gerontology \& Geriatrics, 3, 142-144. doi: 10.15406/Mojgg.2018.03.00102

Bertogg, A. ve Strauss, S. (2020). Spousal caregiving arrangements in europe. the role of gender, socio-economic status and the welfare state. Ageing \& Society, 40, 735-758. doi: 10.1017/S0144686X18001320

Bertram, S. (1989). The ashes and the flame: passion and aging in classical poetry. T. M. Falkner ve J. De Luce (Ed.), Old age in Greek and latin literature içinde (157-172). Albany: State Universty Of New York Press.

Blomé, M. W., Borell, J., Håkansson, C. ve Nilsson, K. (2020). Attitudes toward elderly workers and perceptions of integrated age management practices. International Journal of Occupational Safety and Ergonomics, 26(1), 112-120. doi: $10.1080 / 10803548.2018 .1514135$ 
Breheny, M. ve Severinsen, C. (2018). Is social isolation a public health issue? a media analysis in Aotearoa/New Zealand. Critical Public Health, 28(4), 484-493. doi: $10.1080 / 09581596.2017 .1400162$

Canatan, A. (2016). Yaşlılıkta Sosyal İlişkiler ve Kuşaklararası Etkileşim. Harun Ceylan (Ed.). Yaşlılık sosyolojisi içinde (139-155). Ankara: Nobel Akademik Yayıncılık.

Ceylan, H. (2015). Yaşlanan türkiye'de yaşlı bakım personeline duyulan ihtiyaç ve yaşlı bakım programlarının önem. Electronic Journal of Vocational Colleges, 5(5), 61-68

Chasteen, A. L., Pichora-Fuller, M. K., Dupuis, K., Smith, S. ve Singh, G. (2015). Do negative views of aging influence memory and auditory performance through self-perceived abilities?. Psychology And Aging, 30(4), 881-893. Doi: 10.1037/A0039723

Chonody, J. M. ve Teater, B. (2016). "Why do i dread looking old?: a test of social identity theory, terror management theory, and the double standard of aging. Journal Of Women \& Aging, 28(2), 112-126. Doi: 10.1080/08952841.2014.950533

Çayır K. (2012). Yaşçılık/Yaşa Dayalı Ayrımcılık. Ayrımcılık Çok Boyutlu Yaklaşımlar, Derleyenler: Kenan Çayır, Müge Ayan Ceyhan, İstanbul Bilgi Üniversitesi Yayınları 393, 1. Bask1, İstanbul, 163-174.

Durkheim, E. (1962). Meslek Ahlakı. M. Karasan (Çev.). Ankara: Milli Eğitim Basımevi.

El Haj, M., Jardri, R., Larøi, F. ve Antoine, P. (2016). Hallucinations, loneliness, and social isolation in alzheimer's disease. Cognitive Neuropsychiatry, 21(1), 1-13. Doi:10.1080/13546805.2015.1121139

Ertin, H. ve Özkaya, H. (2016). Etik Açıdan Yaşlıya Kötü Muamele/İstismar ve Toronto Bildirgesi. Türkiye Klinikleri Journal of Medical Ethics, Law and History-Special Topics, 2(2), 77-84.

Faronbi, J. O., Adebowale, O., Faronbi, G. O., Musa, O. O. ve Ayamolowo, S. J. (2017). Perception knowledge and attitude of nursing students towards the care of older patients. International Journal Of Africa Nursing Sciences, 7, 37-42. doi:10.1016/J.İjans.2017.06.004

Fee, A., McIlfatrick, S., and Ryan, A. (2021). 'When it faded in her ... it faded in me': A qualitative study exploring the impact of care-giving on the experience of spousal intimacy for older male care-givers. Ageing and Society, 41(1), 29-50. doi:10.1017/S0144686X19000850 
Feng, J., Chuai, X., Lu, Y., Guo, X. ve Yuan, Y. (2020). Who Will do more? the pattern of daily out-of-home activity participation in elderly co-residence households in urban china. Cities, 98(102586), 1-10. doi:10.1016/J.Cities.2019.102586

Fernández-Ballesteros, R., Zamarrón, M. D., Díez-Nicolás, J., López-Bravo, M. D., Molina, M. Á. ve Schettini, R. (2011). Productivity in old age. Research On Aging, 33(2), 205-226. doi:10.1177/0164027510395398

Görgün Baran, A., Kalınkara, V., Aral, N., Baran, G., Akın, G. ve Özkan, Y. (2005). Yaşlı ve Aile İlişkileri Ankara Örneği. Ankara: Aile ve Sosyal Araştırmalar Genel Müdürlüğü Yayınları.

Görgün Baran, A. (2018). Yaşlanma. E. B. Sağlam, A. Öğün Boyacıŏglu, A. Gelgeç Bakacak, (Ed.). Sosyoloji içinde (586-615). Ankara: Siyasal Kitabevi.

Gürşahbaz, N., Özelmas Kahya, S. ve Arga Şahinoğlu, M. (2009). Yaşlı kadın tüketicilerin hazır giyim ürün tercihlerini etkileyen unsurların belirlenmesi üzerine bir araştırma. Yaşsl Sorunları Araştırma Dergisi, 2(2), 146-157.

Higgs, P. ve Jones, I. R. (2009). Medical Sociology and Old Age: Towards a Sociology of Health in Later Life. New York And London: Routledge.

Kaçar, N. (2019). Yaşlı tüketiciler ve giyim estetiği: sosyal ve psikolojik etkenlerin davranışa etkileri. Yaşlı Sorunları Araştırma Dergisi, 12(1), 52-59.

Kalaycı, I., Çelikkol, Ö. ve Küpeli, A. (2014). The effects of chronic diseases on the old people's lives and ideas: Süleyman Demirel University sample. European Journal of Research on Education, , Special Issue: Contemporary Studies in Social Science,145-150.

Kalayc1, I. ve Özkul, M. (2017). Geleneksel kalabilsem modern olabilsem: modernleşme sürecinde yaşl111k deneyimleri. Süleyman Demirel Üniversitesi Vizyoner Dergisi, 8(18), 90-110. doi:10.21076/Vizyoner.308309

Kalayc1, I. ve Özkul, M. (2018). Old Age in Theories. B. Yenihan, D. Başar, G. Cerev, (Ed.), A Critical Review Of Social Sciences Theory And Practice içinde (429-437). India: Frontpage.

Kalınkara, V. (2011). Temel Gerontoloji Yaşlılık Bilimi. Ankara: Nobel Akademik Yayıncılık.

Kalınkara, V. ve Kalaycı, I. (2017). Yaşlıya evde bakım hizmeti veren bireylerde yaşam doyumu, bakım yükü ve tükenmişlik. Yaşlı Sorunları Araştırma Dergisi, 10(2), 19-39.

Kim, Y. B. ve Lee, S. H. (2018). Effects of the elderly's health statuses, health behavior, and social relations on their health-related quality of life: focusing on family types. Journal 
of Korean Academy of Community Health Nursing, 29(3), 310-321. doi: 10.12799/Jkachn.2018.29.3.310

Kim, J. H. (2019). Productive Aging of korean older people based on time use. Social Science \& Medicine, 229, 6-13. doi: 10.1016/J.Socscimed.2018.04.020

Kotter-Grühn, D., Neupert, S. D. ve Stephan, Y. (2015). Feeling old today? Daily health, stressors, and affect explain day-to-day variability in subjective age. Psychology \& Health, 30(12), 1470-1485. doi: 10.1080/08870446.2015.1061130

Löckenhoff, C. E., De Fruyt, F., Terracciano, A., Mccrae, R. R., De Bolle, M., Costa, P. T., ... ve Allik, J. (2009). Perceptions of aging across 26 cultures and their culture-level associates. Psychology and Aging, 24(4), 941-954.

Malik, R. T., Ayaz, A. ve Hussain Bhutto, Z. (2016). Interrelation of perception of old age and respect toward old people among young adults. Bahria Journal of Professional Psychology, 15(2), 95-112.

Mathur, S. (2015). Social support network analysis of the elderly: gender differences. International Journal Of Humanities \& Social Science Studies, 2(1), 168-175.

Mendoza-Núñez, V. M., Sarmiento-Salmorán, E., Marín-Cortés, R., Martínez-Maldonado, M. D. L. L. ve Ruiz-Ramos, M. (2018). Influence of the self-perception of old age on the effect of a healthy aging program. Journal of Clinical Medicine, 7(106), 1-11. doi:10.3390/Jcm7050106

Nazlıer-Keser, E.N. (2020). Yaşlı bakım uygulamalarındaki etik sorunlar üzerine bir değerlendirme. Toplum ve Sosyal Hizmet, 31(1), 303-333. doi: 10.33417/Tsh.681896

Özcan, G. (2013). Yaşlılık ve Din. N. Akyüz ve İ. Çapcioğlu (Ed.), Din Sosyolojisi içinde (253267). Ankara: Grafiker Yayınları.

Özkul, M., Kalaycı, I. ve Atasoy, M. (2019). Yaşlıların toplumsal ilişki kurma biçimleri: sorunlar ve imkânlar. Sosyal Bilimler Dergisi, 6(37), 77-97. doi: 10.16990/SOBIDER.5051

Penninx, B. W., Messier, S. P., Rejeski, W. J., Williamson, J. D., Dibari, M., Cavazzini, C., ... ve Pahor, M. (2001). Physical exercise and the prevention of disability in activities of daily living in older persons with osteoarthritis. Arch Intern Med, 161(19), 2309-2316.

Salar, S., Günal, A., Pekçetin, S., Huri, M., Mehr, B. K, Katırcıbaşı, G. ve Uyanık, M. (2018). Yaşlılarda aktivite, çevre ve yaşam memnuniyeti ilişkisi. Ergoterapi ve Rehabilitasyon Dergisi, 4(2), 89-96. 
Sever, Ö. ve Başıüyük Özgün, G. (2009). Yaşlı dul kadınlık. Yaşlı Sorunları Araştırma Dergisi, 2(2), 136-145.

Shahar, S. (1998). Old age in the high and late middle ages: image, Expectationand status. P. Johnson Ve P. Thane, (Eds.), Old age from antiquity to postmodernity içinde (43-64). London And New York: Routledge.

Stephan, Y., Sutin, A. R. ve Terracciano, A. (2016). Feeling older and risk of hospitalization: evidence from three longitudinal cohorts. Health Psychology, 35(6), 634-637. doi: $10.1037 / \mathrm{Hea} 0000335$

Şenol, D. ve Erdem, S. (2017). Yaşlılık ve yaşlı kadınlarda huzurevi algısı: nitel bir araştırma. Kırıkkale Üniversitesi Sosyal Bilimler Dergisi, 7(2), 31-50.

Thyagarajan, B., Shippee, N., Parsons, H., Vivek, S., Crimmins, E., Faul, J. ve Shippee, T. (2019). How does subjective age get under the skin? The association between biomarkers and feeling older or younger than one's age: the health and retirement study. Innovation in Aging, 3(4), 1-11. doi: 10.1093/Geroni/İgz035

Timurturkan, M. ve Demez, G. (2018). Bir toplumsal iktidar alanı olarak beden ve "yaşlanan bedenin” yeniden inşası. Mehmet Akif Ersoy Üniversitesi İktisadi ve İdari Bilimler Fakültesi Dergisi, 5(2), 441-456. doi: 10.30798/Makuiibf.402090

Tufan, İ. (2003). Modernleşen Türkiye'de Yaşlılık ve Yaşlanmak. Anahtar Kitaplar Yayınevi.

Tufan, İ. (2016). Yaşlanan Toplumun Riskleri, Problemleri, İhtiyaçları. H. Ceylan (Ed.), Yaşl1lık Sosyolojisi içinde (99-117), Ankara: Nobel Akademik Yayıncılık.

Türkbeyler, İ. H., Öztürk, Z. A., Kalem, A. ve Abiyev, A. (2018). Gelişen ve Yaşlanan Toplumumuzda Yaşlılık Algısı. Nobel Medicus, 14(2), 17-21.

Türkiye İstatistik Enstitüsü. (2016). Aile Yapısı Araştırmas1, 2016. Erişim 08 Temmuz 2020, http://www.tuik.gov.tr/prehaberbultenleri.Do?Id=21869.

Türkiye İstatistik Enstitüsü. (2020) Adrese Dayalı Nüfus Kayıt Sistemi Sonuçları, 2019). Erişim 04 Temmuz 2020, http://www.Tuik.Gov.Tr/Prehaberbultenleri.Do?İd=33705.

United Nations (2017). Ageing. Erişim 05 Ağustos 2020, https://www.Un.Org/En/Sections/İssuesdepth/Ageing/

Viana Medeiros, D., Santos, W. N. D., Das Graças De Melo Sousa, M., De Cássia Dias Da Silva, T., Silva, P., Teles, P. ve De Fátima Ferreira De Castro, S. (2016). Elderly's perception of old age. Journal of Nursing UFPE, 10(10), 3851-3859. doi: 10.5205/Reuol.9667-87805-1-ED1010201617 
Wolff, J. L., Spillman, B. C., Freedman, V. A. ve Kasper, J. D. (2016). A national profile of family and unpaid caregivers who assist older adults with health care activities. JAMA Internal Medicine, 176(3), 372-379. doi:10.1001/Jamainternmed.2015.7664

Yazıcı Özbek, S., Kalaycı, I., Kaya, E. ve Tekin, A. (2015). Yaşlı bakım programı öğrencilerinin yaşlı ayrımcılığına ilişkin tutumları. Yaşlı Sorunları Araştırma Dergisi, 8(2), 77-87.

Yazıcı Özbek, S., Kalaycı, I., Kaya, E. ve Tekin, A. (2016). Attitudes of students studying in health related departments towards the elderly. Gaziantep University Journal Of Social Sciences, 15(2), 601-614. doi: 10.21547/Jss.256713 